\title{
AGAINST ALVIN PLANTINGA'S REFORMED EPISTEMOLOGY: THE SUFFICIENCY OF EVIDENCE FOR THE BELIEF IN GOD
}

\author{
Alfie A. Polistico, OSJ \\ De La Salle University, Manila, Philippines
}

\begin{abstract}
The paper is a critique of Alvin Plantinga's notion that belief in God is properly basic - evidence is not needed to justify such belief - in light of Thomas Aquinas' religious epistemology. The latter's epistemology proves that, while evidence is not a necessary condition for belief in God based on his Summa Theologica (henceforth, ST) since such belief is evidence itself from his De Veritate (henceforth, Dv), there is sufficient evidence that justifies such belief. First, I argue that Plantinga's total rejection of evidence as a justification for belief in God renders such belief purely subjective. To rationally ground this purely subjective belief, Plantinga introduces the notion of justification-conferring conditions. Second, following Thomas Aquinas' thought, Plantinga's justification negates his claim that belief in God is properly basic because the said justification-conferring conditions seem to function as an evidence for belief in God. I will conclude the work by claiming that although evidence is not a necessary condition for belief in God, it is epistemically sufficient to justify the said belief.
\end{abstract}

\section{INTRODUCTION}

One of the highly contentious topics in contemporary epistemology of religion is the status of evidence as a justification for belief in God. Two schools of thought propound completely opposing views regarding evidence - theistic evidentialism and reformed epistemology. On the one hand, Richard Swinburne $(1996,114)$ argues that there is evidence that "gives a significant degree of probability" that justifies belief in God. On the other hand, Alvin Plantinga (1983, 91), the strongest proponent of reformed epistemology, argues that evidence is not needed to justify belief in God because such belief is properly basic "grounded in justification-conferring conditions." This opposition, roughly speaking, is the present-day tug of war between faith and reason, between fideism and rationalism. ${ }^{1}$

Thomas Aquinas, in his religious epistemology, appears to agree with the two schools of thought. Edmond Eh $(2015,33)$ argues that "in [St. Thomas's] account of religious knowledge by faith argues that evidence is unnecessary for religious beliefs. However, in his account of religious knowledge by science, he argues that there is 
evidence for religious beliefs." Meaning, while evidence is not a necessary condition for belief in God, there is sufficient evidence that justifies such belief.

I advance two points in this paper. First, following Thomas Aquinas' understanding of evidence in relation to belief in God, I claim that Plantinga's total rejection of evidence as a justification for belief in God renders such belief purely subjective. To justify this purely subjective belief, he introduces the notion of justification-conferring conditions. Second, I argue that Plantinga's notion of justification-conferring conditions negates his claim that belief in God is properly basic because the said conditions seem to function as an evidence for the said belief. I accordingly divide the discussion into four parts: the first deals with Thomas Aquinas' religious epistemology; the second deals with Plantinga's reformed epistemology focusing on his notion of proper basicality; the third deals with his justificationconferring conditions; and the last part is my critique of Plantinga's claim that belief in God is properly basic.

\section{THOMAS AQUINAS' TWO FORMS OF KNOWLEDGE OF GOD}

\section{Knowledge of God by Faith}

For Thomas Aquinas (Dv q.14, a. 2, ad. 15), faith is knowledge of objects which are not seen in which "the intellect of the believer is determined to [assent] to one object, not by reason, but by the will" (ST II-II, q. 2, a. 1, ad. 1 \& 3). Its content is not demonstrated by natural reason but is induced in the believer (ST II-II, q. 2, a. 1, ad. 1). The act of faith has three different relations to its object - God. First, as regards the material object of faith, "an act of faith is 'to believe in a God"” (ST II-II, q. 2, a. 2, co.). Second, as regards the formal aspect of the object, "an act of faith is "to believe God"" (ST II-II, q. 2, a. 2, co). Third, "if the object of faith be considered in so far as the intellect is moved by the will, an act of faith is to believe in God" (ST II-II, q. 2, a. 2, co).

Here, knowledge — or belief in God — is gained by the assent of the intellect determined by the will. This assent is "moved by the grace of God" (ST II-II, q. 2, a. 9 , co.). Through this grace, "the believer has sufficient motive for believing" (ST II-II, q. 2, a. 9, co., ad. 3). The justification of the sufficiency of motive cannot be fulfilled by external proofs - provided that grace in this kind of knowledge is an epistemic (therefore, internal) assistance from God-but by freewill, since the believer can choose - or not choose - to assent to the object of faith (ST II-II, q. 2, a. 9, co., ad. 2). Hence, the believer is not obligated to justify her/his faith in God materially because she/he freely chooses to believe in God.

The choice to believe is "to think with assent." This choice or thinking with assent is proof that "one chooses to give intellectual assent to something with certainty" (Eh 2015, 36). What validates this certainty is faith itself because, in its own right, it is an evidence (Dv q. 14, a. 2, ad. 9). For Thomas Aquinas, faith can be called evidence in four ways. First, faith can rightly be considered as evidence because "reason assents to something because it was said by God." Implied in this assent is the authority of the speaker, who is God. Second, faith can be called as evidence insofar as the said faith acts as a means to prove God's existence. Third, "faith is a brief 
foretaste of the knowledge which we shall have in the future." Fourth, "faith is evidence with reference to the light of faith through which we know what is to be believed" (Dv q. 14, a. 2, ad. 9).

The four ways epistemically show that faith — knowledge of objects which are not seen - proves God's existence. In short, there is faith because God truly exists. Knowledge by faith functions as a medium through which God is thought to be truly existing. Faith is an epistemic bridge between human rationality and God. The certainty of this kind of knowledge rests on the truthfulness of God as its object. The free assent of the believer is her/his cooperation with the epistemic aid provided by God himself in the form of grace, as noted by Thomas Aquinas.

\section{Knowledge of God by Science}

For Thomas Aquinas (ST I, q. 84, a. 1, s. c.), "science is in the intellect." This is so because the bodies that are in a continual state of flux "cannot be grasped with any degree of certitude" (ibid.). In science, there are two dimensions of human knowledge: the sensible knowledge and the intellectual knowledge (ST I, q. 85, a. 3., co.). The object of the former is singular and individual, while the object of the latter is universal. Sensible knowledge comes before intellectual knowledge. Through abstraction - the operation of the intellect to form a universal concept after the actual sensation - the soul [through the intellect] "knows bodies by understanding them, not indeed through bodies, nor through material and corporeal species; but through immaterial and intelligible species, which can be in the soul by their own essence" (ST I, q. 84, a. 1, ad. 1).

In this paradigm, the soul's intellect has the power to access the essence of things. The intellect's proper and proportionate object is the nature of a sensible thing" (ST I, q. 84, a. 8, co.). However, "the suspension of the senses necessarily involves a hindrance to the judgment of the intellect" (ST I, q. 84, a. 8, co., ad. 1). Meaning, while the intellect knows more perfectly than the senses, the former cannot operate without the data provided by the latter. The complementary relationship between the two dimensions of knowledge will be demonstrated in the following paragraphs.

\section{The Sensitive Dimension of Human Knowledge}

The essence of the knowledge of God by science is reasoning (ST I, q. 85, a. 5, co.). The first step of knowing is external sensation. By external sensation, we mean "the soul senses nothing without the body because the action of sensation cannot proceed from the soul except by a corporeal organ" (ST I, q. 77, a. 5, ad. 3) through its five exterior senses: sight, sound, smell, taste, and touch. This is the first phase in the human cognitive process in which cognitive, physical act is caused by a stimulus. This is the immediate contact of the concrete. The stimuli excite the organs causing the latter to transmit raw information to the central nervous system. When sensibility works, individuated by the different sense organs such as nose, ears, eyes, and the like, the physical contact excites the nervous system. For example, when one smells something bad, the smell itself is the stimulus, while "smelling something bad" is the excitation. The immediate reaction of the brain is the sensation. It is the actual here and now. 
During sensation, the mind is not involved yet because the body is about to relay sense data to it in a split second.

Next is internal perception. Internal perception "is the power that preserves the sense data ...where their forms are apprehended" in the soul (ST I, q. 78, a. 4). These inchoate forms are called phantasms which are organized in such a way that each datum is placed accordingly. Here, the mind actively puts everything received from the actual sensation in order. Ramon Lucas (2005, 113-117), in trying to illustrate how internal perception operates, uses some vague black and white images of children, buildings, and beds. No matter how vague these images are, the mind can still figure out what the images really depict. This is what internal perception does with the data provided by the actual sensation. Internal perception puts everything in order in such a way that the data can still be well known though they are presented to us vaguely in some instances.

\section{Intellectual Dimension of Human Knowledge}

Next is conceptualization. Here, the intellect "makes things actually intelligible, by abstraction of the species from material conditions" (ST I, q. 79, a. 3). After sensation, the mind starts to organize the details which the phantasms provide. Phantasms are data that are taken from the actual sensation. Through these, the mind forms concepts that are immaterial and unchangeable which correspond to particular things. The mind abstracts the universal, which applies to the same particular beings actually sensed. Thus, the concept of a horse applies to all horses because the phantasms being provided are the representations of the same bodies that do not change the moment they are conceptualized. That is why, no matter how one revises the actual image of a horse, be it a paper horse, actual horse, painting of a horse, clay horse, and the like, the "horseness" of these material horses is still the same, i.e., universally unchangeable.

Then follows judgment. Through judgment, the mind affirms or denies what is conceptualized. While conceptualization is the acquisition of some raw images provided by phantasms, judgment "answers the question, 'Is it so?"' When we see a thing, and when that thing corresponds to the criteria of being a bird, then we judge, "This is a bird." Affirmation and negation of what is conceptualized depend on the fact that "that thing is not this thing." Background knowledge has a strong influence on the knowing process; that is why strong judgment requires much experience.

The culmination of the process of knowing is reasoning. Reasoning is our "power to move from understanding to inquiry, discovery, analysis, and judgment" (ST I, q. 79, a. 8). Reasoning is "a physical activity of the cognitive order whose end is to formulate judgment...by reason of a necessary connection between the truths presupposed by the judgments given and the new judgment that it is going to formulate" (Lucas 2005, 144145). It is the capacity of the mind to formulate some judgments in order to arrive at some truths. Thus, the aim of reasoning is to provide ideas that will support what is claimed to be true. Reasoning shows the connection between concepts in a discursive way.

\section{Evidence for God's Existence}

Following the complementary relationship between the sensitive and intellectual dimensions of knowledge, Thomas Aquinas (ST I, q. 12, a. 1, co.) argues 
that the intellect can see God's essence. He justifies this kind of seeing by the principle of causality. First Thomas (ST I, q. 2, a. 1, co.) proves that the existence of God is evident. An existence can be evident in two senses-first, it is self-evident in itself but not to us; second, it is self-evident in itself and to us. If we accept that God's existence is self-evident in the second sense, a demonstration is no longer needed. This kind of selfevidence is already shown plausible in the context of knowledge of God by faith. If selfevident is understood in the first sense, then demonstration is needed.

Thomas argues that such demonstration can be proved by effects - demonstration a posteriori. "When an effect is better known to us than its cause, from effect, we proceed to the knowledge of the cause. And from every effect, the existence of its proper cause can be demonstrated, so long as its effects are better known to us; because since every effect depends upon its cause, if the effect exists, the cause must pre-exist" (ST I, q. 2, a. 2 , co.). Therefore, an effect is evidence for the existence of the cause. For him, there are five ways to prove God's existence (ST I, q. 2, a. 3, co).

The first and "the more manifest way" is the argument from motion. After observing series of sensible motions, Thomas (ST I, q. 2, a. 3, co) argues that "it is necessary to arrive at a first mover, put in motion by no other; and this everyone understands to be God." The second way is "from the nature of efficient cause." From the examination of the nature of the efficient cause, "it is necessary to admit a first efficient cause, to which everyone gives the name of God" (ST I, q. 2, a. 3, co). The third way is taken from possibility and necessity. Here, Thomas argues that, after seeing that almost everything is contingent, "we postulate that God is a being having [in] itself its own necessity... and causing in others their necessity" (ST I, q. 2 , a. 3, co). The fourth is from the gradation to be found in things. Thomas claims that "there must be something which is to all beings the cause of their being, goodness, and every other perfection; and this we call God" (ST I, q. 2, a. 3, co). The fifth way is from the governance of the world. Seeing the design and order of the universe, he argues that it is God "by whom all natural things are directed to their end" (ST I, q. 2, a. 3, co).

From the principle of causality, Thomas proves that sensible effects in the universe are proofs of God's existence who is the prime mover, the first efficient cause, the necessary being, the most good and most perfect being, and finally, the intelligent designer of everything. Causality, in the mind of Thomas Aquinas, does not presume that God is the most and the best. What it actually shows is that God is Ipsum Esse Subsistens, that is, God is Subsistent Being Itself. He is the ground and goal of all beings. Thomas Aquinas (ST I, q. 25, a. 3, co.) argues that " $[\mathrm{t}]$ he divine existence... upon which the nature of the power of God is founded, is infinite and is not limited to any genus of being...[He] possesses within [Himself] the perfection of all being."

\section{PLANTINGA'S REFORMED EPISTEMOLOGY}

\section{Theistic Evidentialism}

Theistic evidentialism is a form of evidentialism rooted in Natural Theology through which sufficient evidence for belief in God is accessed. Richard Swinburne 
$(1996,55)$ argues that "the existence and regular behavior of material objects provide good evidence for the existence of God." He $(1996,68)$ furthers that "[ $t]$ he very success of science in showing us how deeply orderly the natural world provides strong grounds for believing that there is an even deeper cause of that order." Order in nature is proof of its designer. Order, as an effect, is a hint of its agent, the cause. Syllogistically, it can be expressed as:

(1) If there is an effect, then there is a cause.

(2) There is an effect.

(3) Therefore, there is a cause.

(1) If the universe is ordered, then there is an orderer.

(2) The universe is ordered.

(3) Therefore, there is an orderer.

Like Swinburne, the atheist-turned-theist philosopher Anthony Flew (2007, 95) believes that "the most popular and intuitively plausible argument for God's existence is the so-called argument from design." Flew (2007, 96-112) argues that laws of nature-laws that govern the regularities in nature are "mathematically precise, universal, and 'tied together'" - have provenance in God. Following the thoughts of some of the world-renowned scientists like A. Einstein, M. Planck, W. Heisenberg, Erwin Schrödinger, and Paul Dirac, he contends that the rationality of nature [on the part of science] is related to the mind of God. Flew $(2007,112)$ writes:

Those scientists who point to the Mind of God do not merely advance a series of arguments of a process of syllogistic reasoning. Rather, they propound a vision of reality that emerges from the conceptual heart of modern science and imposes itself on the rational mind. It is a vision that I personally find compelling and irrefutable.

Some analytic philosophers of religion like George I. Mavrodes and William L. Rowe also argue for the importance of evidence. As examined by Philip L. Quinn (2002, 515), these philosophers show that "a proof is supposed to be a discursive argument for its conclusion; a proof is also supposed to be a cognitive achievement of some sort. To put the point modestly, perhaps a proof is supposed to raise the epistemic status of its conclusion above what that status would be in the absence of the proof." Quinn $(2002,516)$ cites Mavrodes' argument to show the importance of proof in an argument for God's existence:

(1) Either nothing exists, or God exists.

(2) Something exists.

(3) Therefore, God exists.

In his analysis of the argument, Quinn $(2002,516)$ writes: 
This argument is a deductively valid disjunctive syllogism. Its second premise is obviously true. Since its first premise follows deductively from its conclusion, it is a sound argument if God exists. Suppose that God does exist. The argument is then a sound argument for the existence of God.

To strengthen the status of proof further, Quinn cites Rowe's The Cosmological Argument's concluding chapter entitled The Cosmological Argument as a Justification for Belief in God. "Like Mavrodes," Quinn $(2002,518)$ writes, "Rowe insists that an argument must satisfy epistemic conditions if it is to account as a proof for the existence of God." As quoted by Quinn (2002 [Rowe 1975, 254]), below are the five necessary conditions for being a proof of God's existence:

(i) The conclusion asserts or entails (in some fairly obvious way) that God exists. (ii) The conclusion must follow from the premises of the argument. (iii) The premises of the argument must be true. (iv) The premises of the argument are known to be true. (v) The premises are known independently of any knowledge of the conclusion.

From Quinn's examination of Mavrodes' deductive argument and Rowe's inductive argument, it is conclusive that proof is sufficient to justify belief in God. By showing that proof is both deductively and inductively accessible, belief in God can now be epistemically justified.

\section{Reformed Epistemology}

Peter Forrest (1997 [2017], 8) notes that reformed epistemology is an "influential contemporary rejection of evidentialism due to [Nicholas] Wolterstorff (1976) and Plantinga (1983)." Between them, Plantinga "has clearly been the leading contemporary advocate of this school of thought in religious epistemology" (Quinn 2002, 524-525). It is "reformed" because the two leading proponents are heavily influenced by reformed thinkers such as John Calvin and Abraham Kuyper (Anthony Bolos and Kyle Scott n.d., 3). Calvinist influence - the concept of sensus divinitatiscan be gleaned from Plantinga's Warranted Christian Belief (2000, 126): “[A] believer in God might think that there is such a thing as Calvin's sensus divinitatis [a rational faculty], a natural, inborn sense of God or of divinity, that is the origin and source of the world's religions." Later, this rational faculty will be used by Plantinga in his discussion of belief in God as properly basic.

Wolterstorff $(1983,6)$ believes that evidentialism is the "form assumed by the vision of Enlightenment when it comes to matters of religion." For him, evidentialists advance two claims: (1) "No religion is acceptable unless rational." (2) "No religion is rational unless supported by evidence" $(1983,6)$. Wolterstorff $(1983,14-15)$ counters this position by claiming that "“[to] know' has the sense of acknowledge, as it frequently does in the Bible, trusting God is knowing God. To have faith in God is to know him; to know God is to have faith in him." 
Aside from Wolterstorff and Plantinga, John Hick and William Alston also contend that religious belief is rational even without proof.

Grounded on the fact that experienced-based theistic belief predates all forms of proofs of God's existence that seemingly function as a "conclusion of an inference" in order to convince people outside the realm of faith, Hick $(1971,108)$ argues that the proper philosophical approach to "a living and operative belief" is to explore its "actual foundations" rather than exploring the "theoretical and non-operative arguments subsequently formulated for holding [such belief]." In line with this, it is not the propositioned belief that is worth examining because propositions cannot be rational or irrational but can only be either true or false. "It is people who are rational or irrational, and derivately [sic] their states and their actions, including their acts and states of believing" (Hick 1971, 109). While a believer cannot prove that God exists, "it may nevertheless be possible for him to show it to be wholly reasonable for him to believe that God exists."

In a similar vein, Alston $(1991,68)$ shows that religious experience makes it possible to perceive God and that this possibility can be realized. In realizing such possibility, he contends that "putative experience of God provides justification for beliefs about God, that provides very strong support for supposing that such experiences are, at least frequently, genuine perceptions of God" (Alston 1991, 68-69). What justifies these beliefs is mystical perception - not inferior to sense-perceptionwhich "provides a basis for beliefs about God, rather than beliefs about the subject's perceptual achievements" (Alston 1991, 77).

\section{Plantinga's Notion of Proper Basicality}

In his Reason and Belief in God, Plantinga (1983, 73-87) argues that belief in God is properly basic, so evidence is not needed to justify such belief. This contention is his reaction against the evidentialists who claim that that it is irrational to believe in God without sufficient justification for that belief. As a reformed epistemologist, he believes that evidence for belief in God is unnecessary and the absence of which does not render the same belief unreasonable. He asks: "Must one have evidence to be rational or reasonable in believing in God?" Before answering this question, he (1983, 75-76) first repudiates the claim of the evidentialists that properly basic beliefs are selfevident, or incorrigible, or evident to the senses. Plantinga $(1983,75)$ expresses the evidentialists' position as follows:

(2) For any proposition $A$ and person $S, A$ is properly basic for $S$ if and only if $A$ is incorrigible for $S$ or self-evident to $S$.

Plantinga (1983, 75, additions mine), in his criticism of the said proposition, writes:

But how could one know a thing like that? What are its credentials? Clearly enough, (2) is not self-evident or just obviously true. But if it is not, how does one arrive at it? What sorts of arguments would be 
appropriate? Of course, a foundationalist [therefore, evidentialist] might find (2) so appealing he simply takes it to be true, neither offering an argument for it nor accepting it on the basis of other things he believes. If he does so, however, his noetic structure will be self-referentially incoherent. (2) itself is neither self-evident nor incorrigible; hence if he accepts (2) as basic, the modern foundationalist violates in accepting it the condition of proper basicality he himself lays down.

In short, Plantinga $(1983,76)$ sees the evidentialists' proposition as epistemically faulty. It is so because proper basicality does not "follow from clearly self-evident premises by clearly acceptable arguments." Clearly, just because one believes in something does not mean that she/he has to reasonably ground it on other beliefs. The three criteria, therefore, do not guarantee proper basicality. In a way, Plantinga (see 1983, 76) appears to say that if one remembers - therefore believes - that she/he cooked adobo this morning - provided that she/he does not doubt her/his memory - then that memory or belief is basic. There is no need for one to anchor that belief on some other rational grounds. Basicality itself is the very foundation of such itself.

If the evidentialists' understanding of basicality is faulty, what is proper basicality then for Plantinga? He contends that belief in God is properly basic when the object (God) of such belief is personally experienced. He $(1983,77)$ furthers: "my being appeared to redly, for example, is both necessary and sufficient [condition] for my being justified in taking it as basic that I am appeared to redly." In the context of the one seeing God, this example can be paraphrased: "seeing God, for example, is both necessary and sufficient for my being justified in taking it as basic that I am seeing God." After many years, Plantinga $(2000,148)$ still defends his notion of proper basicality: "belief can be properly basic for a person in the sense that it is indeed basic for him (he does not accept in on the evidential basis of other propositions) and, furthermore, he is justified in holding it in the basic way [epistemic honesty]." While there is no fixed criterion of proper basicality, one's belief can be properly basic in the sense that one has an experience of God or is in the conditions that allow him/her to know God, such as reading the Bible, having a deeper sense of everything that is, an experience of forgiveness, the capacity to love and beloved, and feeling of joy and sadness among others. Belief-propositions — "God is calling me," "God is the source of life," "God loves me," "God takes good care of me, and "God is a joyful giver" are also properly basic. In order to ensure basicality, these experiences must be personally meaningful and must not depend on justifying propositions. Although there is no fixed criterion for basicality, personal experience validates it. This personal meaning is experience-based. Perhaps, one believes in God by way of a personal encounter with Him, by way of conversion, or by way of training. Whatever the case may be, Plantinga (2000, 86-87) notes, provided that one's belief is true, one knows that God exists and that is properly basic, that is, meaningful, justified in itself even without evidence.

For him, the proper way to arrive at basicality is by induction. Plantinga (2000, 77) notes that the "[c] riteria for proper basicality must be reached from below rather than above; they should not be presented ex cathedra but argued to and tested by a relevant set of examples." Plantinga (2000) anticipates that not everyone will agree on the 
examples he will be showing to justify induction as a proper way to arrive at basicality. Nonetheless, he proceeds to show that such examples justify his claim. These examples, for him, are very particular to the Christian community. "The Christian community is responsible to its set of examples, not to theirs" [referring to the followers of the atheist evidentialists Bertrand Russell and Madelyn O’Hare] (Plantinga 2000).

Plantinga $(2000,78-79)$ proceeds to prove the claim by enumerating three kinds of beliefs from induction: (1) I see a tree [perceptual beliefs]. (2) I had breakfast this morning [memory beliefs]. (3) That person is in pain [beliefs ascribing mental states to other persons]. (1) (2) (3) are basic provided that the one having these beliefs are epistemically faithful to sense experience. Provided that one is indeed so, there is no need to justify the beliefs because one's epistemic honesty guarantees their truth.

Plantinga $(2000,79)$ furthers that "although beliefs of this sort are taken typically as basic, it would be a mistake to describe them as groundless." A belief is justified for a person at a time if "(a) he is violating no epistemic duties and within his epistemic rights in accepting it then and (b) his noetic structure is not defective by virtue of his then accepting it. Then my being appeared to in this characteristic way (together with other circumstances) is what confers on me the right to hold the belief in question; this is what justifies me in accepting it." Meaning, a belief is justified when one is epistemically honest with the content of sense experience.

Using the same method, Plantinga now attempts to justify belief in God without dependence to any evidence. Like one's workaday experiences [again by induction], there are many instances that drive one to believe in God: "guilt, gratitude, danger, a sense of God's presence, a sense that he speaks, perception of various parts of the universe" (Plantinga 2000, 81). These experiences, he notes, are not the "simple belief that God exists. What we have instead are such beliefs as: (8) God is speaking to me, (9) God has created all of this, (10) God disapproves of what I have done, (11) God forgives me, and (12) God is to be thanked and praised" $(2000,81)$. These propositions (8-12) are properly basic, showing that God exists. "It is not the relatively high-level and general proposition that God exists that is properly basic, but instead propositions detailing some of his attributes or actions" $(2000,81)$. Therefore, both the proposition God exists and propositions 8-12 are properly basic.

\section{PLANTINGA'S JUSTIFICATION}

\section{The Three Justification-Conferring Conditions}

For Plantinga (2000, 82-83), justification-conferring conditions are prima facie conditions though which one's belief - expressed in the proposition (1) God exists implied by propositions 8-12 as enumerated above - is reasonably justified. Justification may take the form of acceptance or denial. As regards the former, one's belief in (1) may be accepted if relevant arguments for it propositionally verify it. As regards the former, one's belief in (1) may be denied if relevant arguments against it propositionally falsify it. Once a theist whose belief in God is properly basic is faced with propositions sufficiently relevant to falsify it, "presumably some change is called for. If he accepts these propositions more strongly than [the proposition God exists]; presumably he will 
give the latter up" (Plantinga 2000, 82). Conversely, once an atheist whose disbelief in God is properly basic is faced with propositions sufficiently relevant to falsify it, "you may cause him to give up a proposition he knows to be true" $(2000,83)$.

Plantinga (2000, 85-86) enumerates three kinds of prima facie justificationconferring conditions: (1) training or teaching, (2) weak/strong justification, and (3) "the conditions that confer prima facie justification do not inevitably include belief."

A good example for training or teaching is a child's acceptance of the teaching given to her/him. "A child is within his epistemic rights in believing what he is taught by his elders" $(2000,85)$. Another example cited by Plantinga is when someone asks for direction from another who knows the place better. Provided that the latter tells the former the truth, the former would believe the latter to be telling the truth. One's belief in God is strengthened (justified) by the testimonies of those who believe in God.

The second justifying condition is propositionally expressed by Plantinga (2000, 85): "a condition satisfied by a person $\mathrm{S}$ and a belief $\mathrm{p}$ when $\mathrm{S}$ is within his epistemic rights in accepting p." $\mathrm{S}$ is justified to believe in $\mathrm{p}$ [there is a brown bird] provided that $\mathrm{S}$ fulfills his epistemic duty-to be honest to the data of experience. This weak justification can become a strong one when "the belief in question is true, then I know it...I am not merely within my rights in believing that [there is a brown bird]; perhaps I have a prima facie obligation to do so [because I truly know it]" $(2000,85)$.

The third justifying condition does not "inevitably include belief." Plantinga $(2000,86)$ writes:

What justifies me in believing that there is a tree present is just that fact that I am appeared to in a certain way [that the tree appears to him in a certain way]; it is not necessary that I know or believe or consider the fact that I am being thus appeared to. What justifies me in believing, on a given occasion, that $2+1=3$ is the fact that it then seems self-evident to me; there is the "clarity and brightness" (Locke) or luminous aura I referred to above. But to be justified it is not necessary that I believe, on that occasion, that my experience is that of character; I need not so much as raise the question. The condition's being satisfied is sufficient for prima facie justification; my knowing and believing that it is satisfied is not necessary.

Here, Plantinga argues that just because something is justified does not necessarily mean that one believes. The self-evidence of something does not epistemically move someone to believe. Hence, on the contrary, self-evidence is not a necessary condition for belief. In this kind of justifying condition, Plantinga reaffirms his position that evidence is not needed to reasonably justify one's belief in God. For him, "belief in God...is not groundless or arbitrary; it is grounded in justificationconferring conditions" (Plantinga 2000, 91).

\section{The Sensus Divinitatis}

Sensus divinitatis [sense of God], Plantinga (2000, 80) notes, "is a tendency or disposition to see [God's] hand in the world about us. More precisely, there is in us a 
disposition to believe propositions of the sort this flower was created by God or this vast and intricate universe was created by God when we contemplate the flower or behold the starry heavens or think about the vast reaches of the universe." Seventeen years after Reason and Belief in God, Plantinga $(2000,148)$ clarifies that it is this sense that produced in a believer theistic belief as basic.

What guarantees the truth of the said propositions is the sense of God itself because this sense is the "truth-aimed" faculty (Plantinga 2000, 126). This sense is "triggered or occasioned by a wide variety of circumstances," including the order and beauty of the universe (Plantinga 2000, 145). Once activated, it becomes an assuring factor that what is observed epistemically is true and therefore basic. Guilt, a feeling that activates the sense of God, is not an evidence for the existence of God, "or for the proposition that he is displeased with me. It is rather that in that circumstance - the circumstance of my clearly seeing my guilt - I simply find myself with the belief that God is disapproving or disappointed" (Plantinga 2000, 146).

"In this regard, the sensus divinitatis resembles perception, memory, and $a$ priori belief [in God]" (Plantinga 2000, 146). Aside from induction, as already noted above, this a priori belief prevents Plantinga from accepting the necessity of evidence in justifying belief in God. If through induction, proved by propositions 8-12, belief in God is properly basic; it is the sense of God that produces theistic belief as basic. Hence, Plantinga succeeded in justifying belief in God deductively and inductively without recourse to evidence.

\section{CRITIQUE OF PLANTINGA'S POSITION}

\section{Plantinga's Pure Subjectivism}

Plantinga's argument based on basicality - that evidence is not necessary to justify belief in God rationally_renders one's belief purely subjective. First, although such belief can be deductively and inductively expressed in a proposition, the only one who can confirm its validity is the one claiming to believe that God exists. While Plantinga does not question the reality of the world outside his mind, he rejects the same reality as a potent evidence for belief in God. Unlike him, Thomas Aquinas, in his knowledge of God by science operating under the principle of causality, proves that the external world is an effect of the reality that God exists. For the latter, this God is the prime mover, the first efficient cause, the necessary being, the most good and most perfect being, and finally, the intelligent designer of everything.

Plantinga overlooks the vitality of the cadence of the universe to rationally ground his belief in God. The reality propounded by the theistic evidentialists, generally operating through the aid of Natural Theology, is for Plantinga $(1983,76)$ grounded on "faulty epistemology" because the criteria-self-evident, incorrigible, evident to the senses - are "self-referentially incoherent." It is incoherent because he believes that the only one who can confirm coherence is the believer herself/himself. This coherence is understood as basicality.

It is only the believer who can validate the basicality of belief in God. Second, Plantinga $(1983,78)$ himself recognizes that there is "no full-fledged criterion of 
proper basicality." This means that anyone can claim that belief in God is basic because one can seemingly ground it rationally. What assures this justification are epistemic honesty and the sensus divinitatis.

In the paradigm of Thomas Aquinas' epistemology, specifically in his understanding of knowledge of God by faith, Plantinga's sensus divinitatis can be understood as God's grace. Both Thomas Aquinas and Plantinga agree that it is God who is the object of faith. By the power of God, the content of faith - by the act of the intellect determined by the will, that faith is a choice-faith is justified. However, unlike Plantinga, Thomas Aquinas treats faith itself as evidence. Meaning, as shown above, the reality of faith is evidence for the existence of God.

By completely rejecting both the inductive and deductive evidence for God, Plantinga becomes purely subjective in his understanding and justification for the belief in God. To escape this intellectual shackle, he introduces the notion of justification-conferring conditions.

\section{Justification-Conferring Conditions as Evidence}

In order to escape the reality of pure subjectivism, ${ }^{2}$ Plantinga introduces the notion of justification-conferring conditions. These conditions are prima facie conditions through which one's belief is epistemically justified. Through these conditions, according to him, belief in God can reasonably be grounded. This seemingly self-coherent grounding is grounded on epistemic honesty. One's epistemic honesty is very crucial to basicality because, as Plantinga $(2000,148)$ notes, "he is within his epistemic rights, is not irresponsible, is violating no epistemic of other duties in holding that belief in that way [as basic]."

Plantinga's understanding of basicality clearly rests on epistemic justification. Justification-conferring conditions ground this kind of justification. The three justifying conditions - (1) training or teaching, (2) weak/strong justification, and (3) "the conditions that confer prima facie justification do not inevitably include belief"function as an evidence for belief in God. Hence, Plantinga negates basicality because a properly basic belief in God does not demand evidence which justificationconferring conditions obviously assume. Without justification-conferring conditions that serve as an evidence, belief in God as properly basic not only renders a believer as purely subjectivist in her/his approach to faith but also makes her/him completely irrational. This is because there can be no objective justification through which she/he can communicate belief in God in a manner that is comprehensible and not selfincoherent.

If belief in God is properly basic, why is there a need to ground it? If basicality reasonably justifies the same belief, why are justification-conferring conditions introduced? Clearly, the answer for this is that basicality must be objective - the quality of belief that has never been rightfully achieved by Plantinga because of the denial of the sufficiency of evidence for belief in God. What Plantinga failed to achieve has been achieved by Thomas Aquinas: while evidence is not a necessary condition for belief because in itself it is already evidence, there is sufficient evidence for belief in God. Thomas Aquinas' demonstration of the complementary role of knowledge of 
God by science and knowledge of God by faith renders belief in God objective justified by God Himself and the available evidence in the universe. Unlike the evidentialists, Thomas Aquinas argues that faith in God-through his exposition of knowledge of God by faith - does not need to be justified because faith itself is evidence for God's existence.

\section{CONCLUSION}

In light of Thomas Aquinas' religious epistemology, it has been found that Plantinga's notion that belief in God is properly basic, that is, evidence is not needed to justify such belief, is purely subjective and epistemically inconsistent. It is purely subjective because it is only the believer who can justify the reasonability of her/his faith and the veracity of the content of the same faith. It is epistemically inconsistent because basicality (no need for evidence) still demands grounding by justificationconferring conditions which epistemically assume the role of evidence.

Indeed, according to Thomas Aquinas, while evidence is not a necessary condition for belief in God because of the reality of knowledge of God by faith, it is nonetheless sufficient to justify the same belief because of the reality of knowledge of God by science.

\section{NOTES}

1. Plantinga clarifies that the Reformed view of belief in God "is not felicitously thought of as a version of fideism" (Plantinga 1983, 91).

2. Plantinga does not want to label his claim as subjectivism but particularism (Plantinga 1983, 78).

\section{REFERENCES}

Alston, William. 1991. Perceiving God: The epistemology of religious experience. Ithaca, New York: Cornell University Press.

Bolos, Anthony and Kyle Scott. n.d. Reformed epistemology. In The Internet Encyclopedia of Philosophy, ISSN 2161-0002. Available at https://www.iep.utm.edu/ref-epis/\#SH2a. Accessed: March 27, 2020.

Eh, Edmond. 2015. Responses to evidentialism in contemporary religious epistemology: Plantinga and Swinburne in conversation with Aquinas. GSTF Journal of General Philosophy_(JPhilo), 1 (2): 33-41. doi: 10.5176/2345-7856_1.2.15. https://www.iep.utm.edu/ref-epis/\#SH2a. Accessed: March 27, 2020.

Flew, Antony. 2007. There is a God: How the world's most notorious atheist changed his mind. New York: HarperCollins e-books. Available at http://93.174.95.29/main/0EB6EA29C7DFA8B70D19ADAA14022643. Accessed: March 22, 2020.

Forrest, Peter. 1997/2017. The epistemology of religion. In The Stanford encyclopedia of philosophy, ed. Edward N. Zalta. Available at 
https://plato.stanford.edu/entries/religion-epistemology/. Accessed: March 23, 2020.

Hick, John. 1971. Arguments for the existence of God. New York: Herder and Herder. Lucas, Ramon. 2005. Man incarnate spirit: A philosophy of man compendium. Translated by Nikola Derpich and Stephen Arndt. Edited by Alex Young and Stephen Arndt. USA: Circle Press.

Plantinga, Alvin. 1983. Reason and belief in God. In Faith and rationality: Reason and belief in God. Edited by Alvin Plantinga and Nicholas Wolterstorff. Notre Dame: University of Notre Dame Press, 16-93.

Plantinga, Alvin. 2000. Warranted Christian belief. Oxford: Oxford University Press. Rowe, William L. 1975. The cosmological argument. Princeton: Princeton University Press.

Quinn, Philip L. 2002. Epistemology in philosophy of religion. In The Oxford handbook of epistemology, ed. Paul K. Moser. Oxford: Oxford University Press, 513-537.

Swinburne, Richard. 1996. Is there a god?. Oxford: Oxford University Press.

Thomas Aquinas. 1953. De veritate. Tr. James V. McGlynn, S.J. Available at https://isidore.co/aquinas/english/QDdeVer14.htm. Accessed: March 29, 2020.

Thomas Aquinas. 1920. Summa theologica. Fathers of the English Dominican Province. Second and Revised Edition. Available at https://www.newadvent.org/summa/1.htm. Accessed: March 29, 2020.

Wolterstorff, Nicholas. 1983. Introduction to faith and rationality. In Faith and rationality: Reason and belief in God, eds. Alvin Plantinga and Nicholas Wolterstorff. Notre Dame: University of Notre Dame Press, 1-15. 